\title{
HA/nylon 6,6 porous scaffolds fabricated by salt-leaching/solvent casting technique: effect of nano-sized filler content on scaffold properties
}

This article was published in the following Dove Press journal:

International Journal of Nanomedicine

10 August 2011

Number of times this article has been viewed

\author{
Mehran Mehrabanian' \\ Mojtaba Nasr-Esfahani² \\ 'Member of Young Researchers \\ Club, Najafabad Branch, Islamic Azad \\ University, Isfahan, Iran; ${ }^{2}$ Department \\ of Materials Science \\ and Engineering, Najafabad Branch, \\ Islamic Azad University, Isfahan, Iran
}

Correspondence: Mojtaba Nasr-Esfahani Department of Materials Science and Engineering, Najafabad Branch, Islamic Azad University, Isfahan, Iran

Tel +983। I 235677 I

Fax +98 3। I 235 677|

Email m-nasresfahani@iaun.ac.ir

\begin{abstract}
Nanohydroxyapatite (n-HA)/nylon 6,6 composite scaffolds were produced by means of the salt-leaching/solvent casting technique. $\mathrm{NaCl}$ with a distinct range size was used with the aim of optimizing the pore network. Composite powders with different n-HA contents $(40 \%$, $60 \%$ ) for scaffold fabrication were synthesized and tested. The composite scaffolds thus obtained were characterized for their microstructure, mechanical stability and strength, and bioactivity. The microstructure of the composite scaffolds possessed a well-developed interconnected porosity with approximate optimal pore size ranging from 200 to $500 \mu \mathrm{m}$, ideal for bone regeneration and vascularization. The mechanical properties of the composite scaffolds were evaluated by compressive strength and modulus tests, and the results confirmed their similarity to cortical bone. To characterize bioactivity, the composite scaffolds were immersed in simulated body fluid for different lengths of time and results monitored by scanning electron microscopy and energy dispersive X-ray microanalysis to determine formation of an apatite layer on the scaffold surface.
\end{abstract}

Keywords: scaffold, nanohydroxyapatite, nylon 6,6, salt-leaching/solvent casting, bioactivity

\section{Introduction}

Designing and fabricating composite scaffolds for bone regeneration from different synthetic biodegradable polymers and bioactive materials is an essential step in engineering bone tissue. ${ }^{1}$ Scaffolds play a critical role in tissue engineering by directing the growth of cells either seeded within the porous structure of the scaffold or migrating from surrounding tissue. ${ }^{2}$ Several methods have been applied to produce polymer-ceramic composite scaffolds for biomedical applications, including thermally induced phase separation (or freeze-drying), ${ }^{3-7}$ solvent casting, ${ }^{8}$ selective laser sintering, ${ }^{9}$ supercritical $\mathrm{CO}_{2}$ antisolvent process, ${ }^{10}$ in situ ceramic particle synthesis by sol-gel process, ${ }^{11}$ precision extrusion deposition, ${ }^{12}$ solid freeform fabrication, ${ }^{13,14}$ electrospinning, ${ }^{15,16}$ ceramic scaffold impregnation by polymer, ${ }^{17,18}$ or, conversely, infiltration of polymer foams via slurry-dipping ${ }^{19,20}$ and even electrophoretic deposition. ${ }^{21}$ However, in the present paper porous scaffolds were produced via saltleaching/solvent casting, a process which is (theoretically) very simple, because it creates the cavities (ie, pores) with desired pore size by washing out the salt particles. With this aim, an ideal salt could be $\mathrm{NaCl}$, since it can easily be removed thanks to its high solubility in aqueous media. Moreover, if trapped in the scaffold, it does not release dangerous ions to the human body, since $\mathrm{Na}^{+}$and $\mathrm{Cl}^{-}$ions are also present in the plasma. ${ }^{22}$ Moreover the salt-leaching procedure proposed here does not require high-temperature heat treatment, which helps to preserve the polymer properties. ${ }^{23}$ 
Nowadays, in order to satisfy the great number of challenging requirements for scaffold materials, such as including biocompatible and bioactive structures, biodegradable systems, interconnected porosities, and mechanical properties similar to natural bone, polymer-ceramic composite scaffolds appear to be an inviting prospect because they combine the advantageous properties of both the constituent phases in an adequately porous structure. ${ }^{24-28}$

Nanohydroxyapatite (n-HA) is an ideal bioactive material whose composition and crystal structure is very close to that of natural bone, and can directly bond to bone tissue in vivo. It has been developed in a variety of forms such as substitute and regeneration material because of its excellent osteoconductivity, osteoinductivity, abrasion resistance, corrosion resistance, and stable chemical properties. But this is exactly what limits its application, because ideal scaffolds should support cell migration and bone growth, in accordance with the rate of material degradation..$^{29,30}$ On the other hand, its brittleness and poor mechanical stability limit its use for the regeneration of load-bearing bone defects. Bone is a biomineralization material made up of collagen, apatite, and water, one-third of which is inorganic and twothirds of which is organic. Nylon has good biocompatibility with human tissue, probably due to its similarity to collagen protein in chemical structure. It has been widely used in the biomaterials application of surgical sutures for nearly half a century. Especially important, nylon also exhibits excellent mechanical properties..$^{31}$ But its degradation is difficult to control. To overcome these shortcomings, the novel porous nanohydroxyapatite/nylon 6,6 (n-HA/nylon 6,6) composite scaffold, which is synthesized from hydroxyapatite and nylon, is fabricated by a salt-leaching/solvent casting technique. High porosity and proper pore size may facilitate cell seeding, survival, growth, differentiation, and proliferation. Investigations have shown that porous n-HA/nylon 6,6 scaffold material could be a good candidate as a bone substitute due to its excellent histocompatibility, osteoconductivity, and osteoinductivity. ${ }^{32}$ The present contribution provides a much deeper insight, adding substantial new information about the n-HA/nylon 6,6 scaffolds obtained via the salt-leaching/ solvent casting technique, focusing on the mechanical and biological behavior as a function of the composite's composition and processing parameters.

\section{Materials and methods Materials}

The polymerization system consists of a cyclohexane phase containing the dichloric acid adipoyl chloride $\left(\mathrm{C}_{6} \mathrm{H}_{8} \mathrm{Cl}_{2} \mathrm{O}_{2}\right.$,
Acros Organics, Geel, Belgium) and a dimethyl formamide (DMF) phase containing the diamine 1,6-hexamethylenediamine $\left(\mathrm{C}_{6} \mathrm{H}_{16} \mathrm{~N}_{2}\right.$, Merck, Darmstadt, Germany) and sodium hydroxide ( $\mathrm{NaOH}$, Merck). The slurry of n-HA used for composites was prepared by our laboratory according to Deng et al. ${ }^{33}$ All solvents were purchased from Merck Group.

\section{Preparation of $\mathrm{n}-\mathrm{HA} / \mathrm{nyl}$ lon 66 composites}

The n-HA/nylon 6,6 composite powder was produced in DMF using the in situ polymerization method. Briefly, n-HA slurry was prepared by a chemical coprecipitation method through aqueous solutions of the reactants according to Deng et al..$^{33}$ The reactants used were of analytical grade. Then, with DMF replacing deionized water at around $153^{\circ} \mathrm{C}$ (boiling point of DMF), a nano-apatite slurry in DMF was obtained. For the in situ polymerization of the neat nylon 6,6 , equimolar monomer, solutions of $0.0244 \mathrm{~mol}$ were made with $1 \mathrm{~mL}$ adipoyl chloride in $30 \mathrm{~mL}$ cyclohexane and $0.71 \mathrm{~mL} \mathrm{1,6-hexamethylene-diamine} \mathrm{in} 30 \mathrm{~mL} \mathrm{DMF}$, which also contained $0.50 \mathrm{~g}$ sodium hydroxide and 40 or $60 \mathrm{wt} \% \mathrm{n}$-HA. After complete mixing, this resultant solution was added slowly into the n-HA slurry in DMF. After the mixing process, the obtained n-HA/nylon 6,6 composite powders were filtered through a Büchner fritted disk funnel and washed repeatedly with distilled water and acetone. Then, powders were dried in a vacuum oven at $80^{\circ} \mathrm{C}$ for 48 hours. Composites with different $\mathrm{n}$-HA percentage were obtained by controlling the weight ratio $(\mathrm{w} / \mathrm{w})$ of $\mathrm{n}-\mathrm{HA}$ to nylon 6,6 during preparation. The measured molecular weight of neat nylon 6,6 synthesized by the in situ polymerization method in the presence of the n-HA with the reagent ratios, as described above, was $14 \mathrm{kDa}$.

\section{Preparation of $n-\mathrm{HA} /$ nylon 6,6 composite scaffolds}

The n-HA/nylon 6,6 composite scaffolds with porous structure were prepared by a salt-leaching/solvent casting technique. Composites with different n-HA percentage of 40 and $60 \mathrm{wt} \%$ were utilized to produce porous scaffolds in a similar process. n-HA/nylon 6,6 composite powder was dissolved in acetic acid ( $\geq 99.5 \%$, Merck) with vigorous stirring for 4 hours at $70^{\circ} \mathrm{C}$ to gain a homogeneous slurry system. The composite powder to acetic acid ratio (w/v) was fixed at 1:3. The salt with optimal pore size ranging from 200 to $500 \mu \mathrm{m}$ was added in the fixed amount ( $70 \mathrm{wt} \%$ of composite powder) and the system was stirred constantly for about 10-15 minutes. The dispersion was then cast into a cylindrical Teflon ${ }^{\circledR}$ mould ( $9 \mathrm{~mm}$ diameter and $18 \mathrm{~mm}$ length, 
suitable for mechanical test) and moved into ultrasonic vibration for 15 minutes. After complete solidification, the porous foam was removed from the mould and the salt and acetic acid were washed out by immersing the samples in distilled water for at least 5 days. The water was refreshed twice a day to help ensure the complete dissolution of the salt. The samples were then washed ultrasonically in deionized water for 24 hours to thoroughly eliminate the remnants of acetic acid. After complete washing of the samples and drying at $100^{\circ} \mathrm{C}$ for another 24 hours, interconnective porous composite scaffolds were obtained. As is known, the resulting porous structure of the scaffolds could have been influenced by various processing parameters, including viscosity-average molecular weight of nylon 6,6 , dispersing temperature, volume of acetic acid, n-HA content, and so on. Thus we fixed all parameters except n-HA content in the composite to study the influence on the morphology and mechanical properties of scaffolds.

\section{Characterization and analysis of n-HA/ nylon 6,6 composite scaffolds}

A transmission electron microscope (TEM, Philips CM 10; Philips, Amsterdam, the Netherlands) was used to examine the microscopic morphology of n-HA powder in slurry and in composite. FT-IR spectra were obtained with a Jasco6300 FT-IR spectrometer (Great Dunmow, Essex, UK). The powders of n-HA, nylon 6,6, and n-HA/nylon 6,6 composite were, respectively, mixed with $\mathrm{KBr}$ and pressed into disks for IR analysis. The spectra were collected over a range of 400 $4000 \mathrm{~cm}^{-1}$. X-ray diffraction (XRD) was used to characterize the crystallinity, chemical composition, and structure of the materials to test the outer surface of the scaffolds directly. The analyses were performed with a Philips X'Pert on n-HA, nylon 6,6, and n-HA/nylon 6,6 composite with 40 and 60 wt $\%$ n-HA, using $\mathrm{CuK} \alpha$ radiation. Scans were performed with $2 \theta$ degree from $10^{\circ}$ to $90^{\circ}$ at a rate of $0.4^{\circ} /$ minute. The porosities of n-HA/nylon 6,6 scaffolds with various n-HA content were evaluated by the method described by Guobao and $\mathrm{Ma}^{34}$ The porosity of the scaffold, $\varepsilon$, was calculated from the measured apparent density $\left(\mathrm{D}_{a}\right)$ and the skeletal density $\left(\mathrm{D}_{s}\right)$ by the formula: $\varepsilon=\left(1-\mathrm{D}_{a} / \mathrm{D}_{s}\right) \times 100 \%$. For each scaffold, five specimens were tested. The assessment of the in vitro bioactivity was carried out by soaking the scaffolds in simulated body fluid (SBF) which was prepared according to Kokubo and Takadama. ${ }^{35}$ For each sample, two fragments (approximately $9 \mathrm{~mm} \times 9 \mathrm{~mm}$ ) were cut and immersed in sterilized polyethylene containers maintained at $37^{\circ} \mathrm{C}$ for 7 and 14 days. When extracted, each sample was rinsed in distilled water, and left to dry at room temperature in a clean place. The morphology of the composite scaffolds before and after soaking in SBF was observed with a scanning electron microscope coupled with energy dispersive X-ray microanalysis (SEM/EDX, Philips XL30), to verify the formation and growth of the apatite layer on the composite scaffold surfaces. The compressive strength and modulus of the composite scaffold were determined using a mechanical testing machine (Reger-3050, Beijing, China). According to the guideline of ASTM standard D 695-96, a cylindrical specimen was prepared with a length twice its diameter. In this study, cylindrical samples were prepared with diameters of $9 \mathrm{~mm}$ and lengths of $18 \mathrm{~mm}$. Four porous samples of each porosity were subjected to this test. The testing conditions were room temperature, at $60 \%$ relative humidity. The crosshead speed was set at $0.5 \mathrm{~mm} /$ minute, and the load was applied until the specimen was compressed to approximately $60 \%$ of its original length. The compressive modulus was calculated as the slope of the initial linear portion of the stress-strain curve.

\section{Results and discussion Characterization of n-HA/nylon 6,6 composite}

Microscopic morphology of n-HA and composite

Figure 1 shows the TEM photographs of the n-HA crystals and the composite powders. Figure 1A indicates that acicular HA crystals are of nanometer grade and have an approximate crystal size of 15-25 $\mathrm{nm}$ in diameter and 35-75 $\mathrm{nm}$ long. The composite particles shown in Figure $1 \mathrm{~B}$ are $20-40 \mathrm{~nm}$ in diameter and 45-80 $\mathrm{nm}$ long. It can be seen that the composite particles are larger in diameter and longer than n-HA crystals with the nylon 6,6 component present on the surface of the n-HA needle crystals. This slight growth in n-HA crystal size may have resulted in condensation and agglomeration of nanocrystals. The apatite crystals in natural hard tissues are formed as thin enamel needles, $5-20 \mathrm{~nm}$ by $60 \mathrm{~nm}$ and
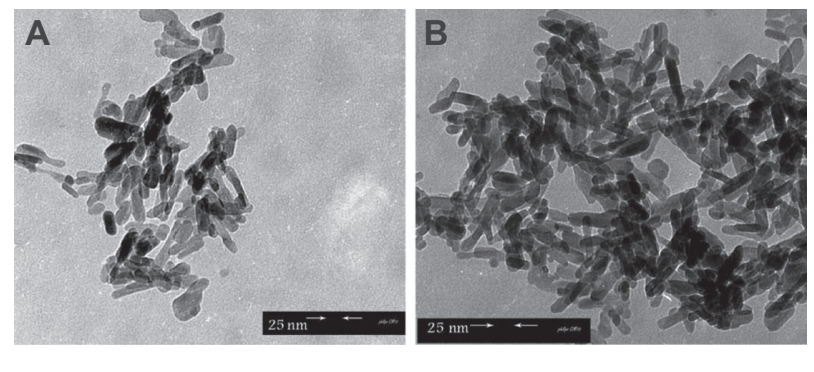

Figure I TEM photographs of n-HA crystals (A) and composite particles (B). 
over $100 \mathrm{~nm}$ long. ${ }^{36}$ The shape and size of the prepared n-HA crystals are similar to the apatite crystals in natural bone, a similarity that is beneficial for making a biomimetic composite. When using the n-HA/nylon 6,6 composite powders to make bulk products, the n-HA crystals can be made to disperse uniformly in the polymer matrix.

\section{IR analysis}

Because both n-HA and nylon 6,6 are polar compounds, the interactions between n-HA and nylon 6,6 can be formed easily through hydrogen bonds. The IR spectrum showing n-HA, nylon 6,6, and n-HA/nylon 6,6 is shown in Figure 2.

1. The absorption peaks of the $\mathrm{OH}^{-}$groups of HA in composites was lower than typical peaks of HA due to the hydrogen bonds between HA and nylon 6,6, which showed a slight shift in the composite;

2. No obvious shift was observed for the absorptions of phosphate bands in composites compared with that in typical peaks of HA, suggesting that almost no bonding occurred between phosphate bands of HA and nylon 6,6. Possibly the atomic structure of $\mathrm{PO}_{4}^{3-}$ does not permit the formation of hydrogen bonds between HA and amide, because three negative charges above three oxygen atoms tend to attract calcium ions intensively, to reach a stable structural form. On the other hand, the orientation property of the hydrogen bonds between $\mathrm{OH}$ of $\mathrm{HA}$ and amide would hamper the formation of hydrogen bonds between them;

3. The stretching vibration frequency of $\mathrm{N}-\mathrm{H}$ groups in nylon 6,6 at $3303 \mathrm{~cm}^{-1}$ changes to $3304 \mathrm{~cm}^{-1}$, whereas the bending vibration frequencies of $\mathrm{N}-\mathrm{H}$ at 1538 and $688 \mathrm{~cm}^{-1}$ move to 1541 and $686 \mathrm{~cm}^{-1}$. The stretching peak of $\mathrm{C}=\mathrm{O}$ in nylon 6,6 rises to $1639 \mathrm{~cm}^{-1}$ in the composite. The peaks of C-H in nylon 6,6 at 2935 and $2859 \mathrm{~cm}^{-1}$ increase slightly to higher wavenumbers of 2937 and $2861 \mathrm{~cm}^{-1}$ in the composite. These spectral shifts indicate that the composition and structure of both components hardly changes after interaction with each other, and that hydrogen bonds exist mainly between the hydroxyl of HA and the amido group of nylon 6,6 because of the variations in their absorption peaks. Moreover, the addition of n-HA crystals into condensed polymer matrix disturbs the strong interaction in nylon molecules and influences their chemical environment. Furthermore, the electronegativity of the oxygen atom is stronger than that of the nitrogen atom, and the attraction of the oxygen in the $\mathrm{OH}^{-}$group of HA to hydrogen is stronger than that of the nitrogen on amide of nylon 6,6 , ie, the positive charge on the hydrogen of $\mathrm{OH}^{-}$is stronger than that of the hydrogen of amide, which makes the formation of

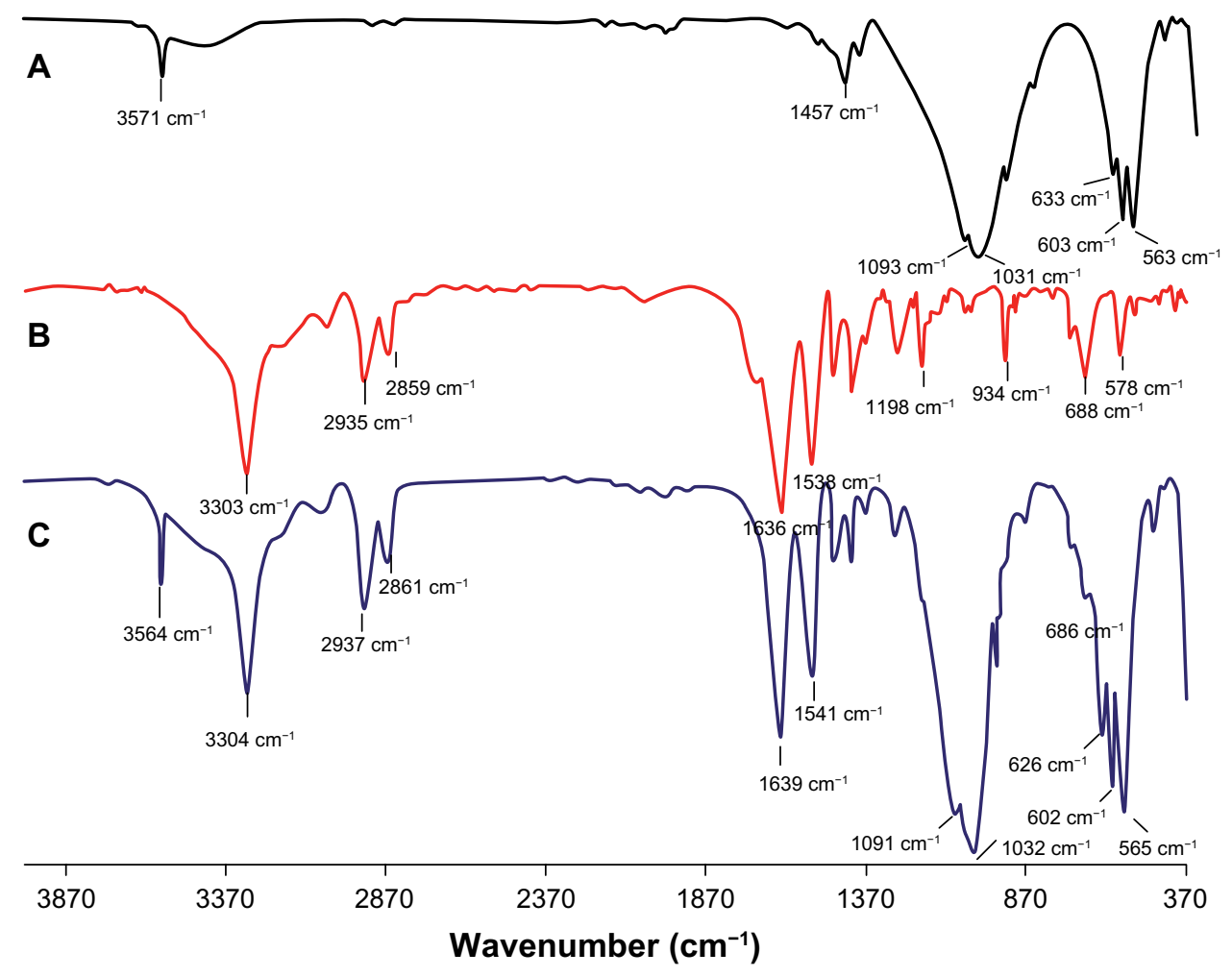

Figure 2 IR spectra of n-HA (A), nylon 6,6 (B) and n-HA/nylon 6,6 nanocomposite (C) powder. 
hydrogen bonds easier between hydrogen of $\mathrm{OH}^{-}$and nitrogen of the amido group than that between oxygen of $\mathrm{OH}^{-}$and hydrogen of amide.

\section{XRD analysis}

Figure 3 shows the XRD patterns of pure nylon 6,6, 40 wt $\%$ n-HA/nylon 6,6 composite, $60 \mathrm{wt} \%$ n-HA/nylon 6,6 composite, and n-HA in powder. Nylon 6,6 has various crystalline phases and usually presents the more stable $\alpha$ phase rather than the $\gamma$ phase in XRD patterns. The two strong diffraction peaks at $2 \theta \approx 20.4^{\circ}$ and $24.1^{\circ}$ are the distinctive feature of the $\alpha$ phase of nylon 6,6 , which are designated as $\alpha 1$ and $\alpha 2$, respectively. The diffraction peak of the $\gamma$ phase is at $2 \theta \approx 21.8^{\circ} .{ }^{37}$ Figure 3 shows that almost all the characteristic peaks of HA appear in the composite powders, while the intensity of these peaks increases with decreased weight percentage of nylon 6,6 . Though the intensities are lower than those of pure nylon $6,6, \alpha 1$ and $\alpha 2$ are still the main diffraction peaks observed in the composite samples and $\gamma$ phase and also appear in the composite powders.

We can draw the following conclusion from the above results:

The intensity change of the nylon 6,6 characteristic peaks after forming the composite, which might be caused by the disturbance of n-HA crystals to the arrangement of nylon 6,6 molecules. Moreover, the introduction of n-HA induces the appearance of the $\gamma$ phase in composites which is unstable and seldom appears in nylon 6,6 at room temperature; more $\mathrm{n}$-HA loadings would amplify this phenomenon. The addition of n-HA also changes the structure of the $\alpha$ crystalline phase. Crystal sizes of n-HA are calculated by Sherrer formula from XRD patterns of different specimens: ${ }^{38}$

$$
\mathrm{D}_{\mathrm{hld}}=\frac{0.89 \lambda}{\sqrt{\mathrm{b}^{2}-\mathrm{b}_{0}^{2} \cos }}
$$

where $\lambda$ is the wavelength, $\theta$ is the Bragg angle, $b$ is the half width of the characteristic peak, and $b_{0}$ is the half width of XRD machine proof-read by multicrystal silicon powder, giving a value of $b_{0}=0.1215$. Table 1 shows the crystal value calculated by the half width and Bragg angle of HA at its characteristic peaks: (002) peak and (300) peak. The data indicate that the size of HA crystals is in nanoscale and the size of HA crystals is bigger in composite than pure HA. This may be attributable to the influence of the process of composite preparation and/ or the interaction between HA and nylon 6,6.

\section{Characterization of n-HA/nylon 6,6 scaffolds Porosity}

The porosity of the scaffold was assessed by comparing the apparent density to the skeletal density. The former was

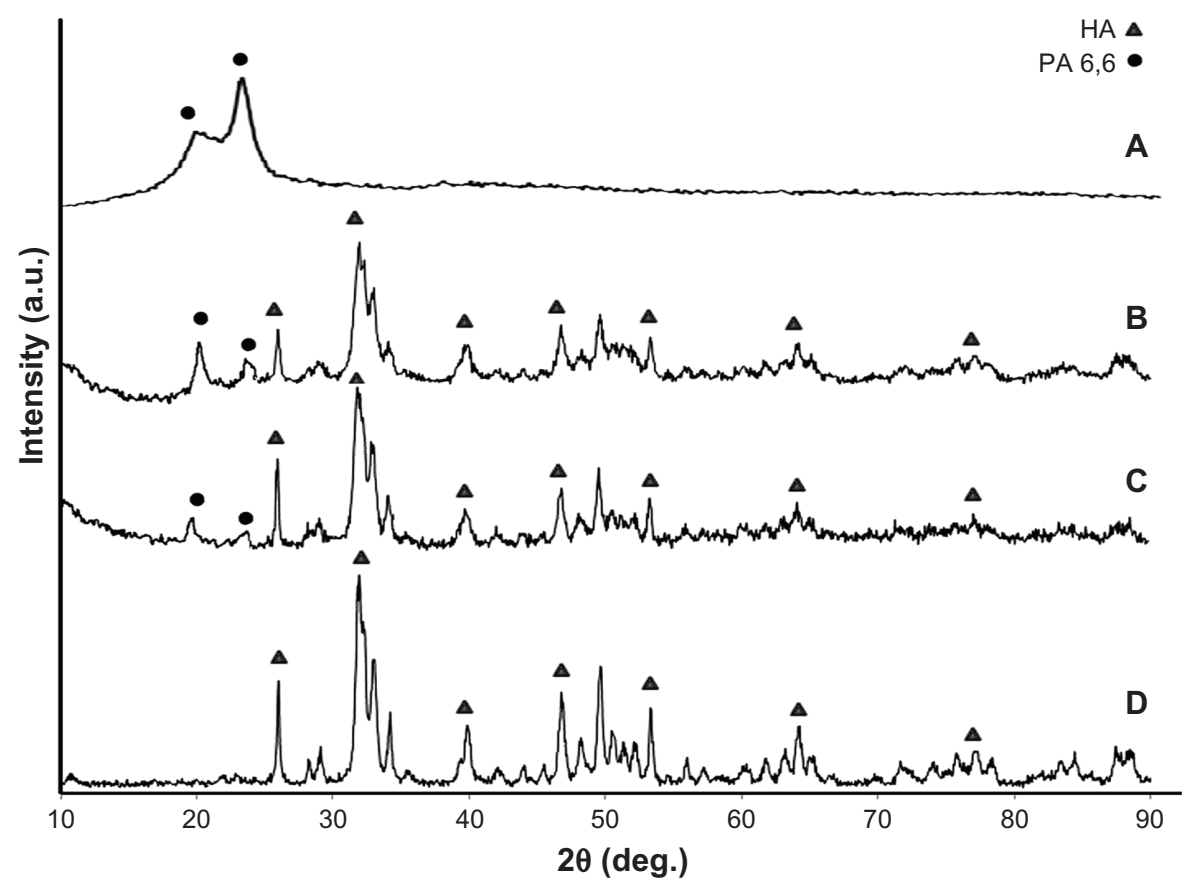

Figure 3 XRD patterns of nylon 6,6 (A), 40 wt\% n-HA/nylon 6,6 composite (B), 60 wt\% n-HA/nylon 6,6 composite (C) and n-HA (D) in powder. 
Table I The crystal size of $n-H A$ in powder materials

\begin{tabular}{lllll}
\hline & $\begin{array}{l}\text { D(hkl) } \\
(\mathbf{n m})\end{array}$ & $\begin{array}{l}\text { Pure } \\
\text { n-HA }\end{array}$ & $\begin{array}{l}\text { 40 wt\% n-HA/ } \\
\text { nylon 6,6 }\end{array}$ & $\begin{array}{l}\text { 60 wt\% n-HA/ } \\
\text { nylon 6,6 }\end{array}$ \\
\hline $\mathrm{n}-\mathrm{HA}$ & $\mathrm{D}(002)$ & 25.3 & 40.4 & 41.5 \\
& $\mathrm{D}(300)$ & 18.2 & 23.1 & 24.9 \\
\hline
\end{tabular}

measured from volume and mass of porous foams. In detail, the scaffolds were cut into cylinders $9 \mathrm{~mm}$ in diameter and $18 \mathrm{~mm}$ high. The skeletal density of the scaffold was calculated using the density of HA and nylon 6,6. Table 2 gives the porosity size of n-HA/nylon6,6 scaffolds with different $\mathrm{n}-\mathrm{HA}$ contents (40 and $60 \mathrm{wt} \%$ ) that resulted a slight change in the mean porosity percentage. The mean porosities of the scaffolds were almost $80 \%$ when the n-HA content was $40 \mathrm{wt} \%$ in the composite. When n-HA content reached $60 \mathrm{wt} \%$, the scaffold still had a high mean porosity of about $75 \%$, which is desirable for tissue-engineering application. ${ }^{39,40}$

\section{Microarchitecture}

Figure 4 shows the microstructure of n-HA/nylon 6,6 scaffold with $40 \mathrm{wt} \% \mathrm{n}-\mathrm{HA}$. The figure shows that the scaffold possesses uniformly distributed cubic pores and uniform pore size with thin pore walls. The investigation of the scaffold morphology showed that most pores were macropores, ranging in diameter from 230 to $485 \mu \mathrm{m}$, which is similiar to the size of $\mathrm{NaCl}$ crystals. It has been reported that pores $>150 \mu \mathrm{m}$ can facilitate internal mineralized bone formation. ${ }^{41}$ Furthermore, micropores with a diameter $<50 \mu \mathrm{m}$ were observed on the walls of the macropores, which will be helpful for fibrovascular colonization and nutrient transportation. The porous structure of the composite scaffold with 40 $\mathrm{wt} \% \mathrm{n}-\mathrm{HA}$ exhibits a high interconnectivity of macropores and micropores. Figure 5 presents SEM photographs of the n-HA/nylon 6,6 porous scaffold with $60 \mathrm{wt} \% \mathrm{n}-\mathrm{HA}$, in which the n-HA content is similar to that in natural bone. This figure shows an abundant and well-developed porosity, with pore sizes similar to the scaffold with $40 \mathrm{wt} \% \mathrm{n}-\mathrm{HA}$. The pore wall thickness is increased in comparison with the scaffold with $40 \mathrm{wt} \% \mathrm{n}-\mathrm{HA}$, typically $48 \mu \mathrm{m}$ to $85 \mu \mathrm{m}$. Figure $5 \mathrm{~B}$ shows that in the microstructure of the pore wall, there are plenty of micropores $<50 \mu \mathrm{m}$ in diameter. Thus we could conclude

Table 2 The mean porosities of n-HA/nylon 6,6 scaffolds with different $\mathrm{n}-\mathrm{HA}$ content

\begin{tabular}{ll}
\hline n-HA Content (wt\%) & Mean porosity (\%) \\
\hline 40 & 80.29 \\
60 & 75.38 \\
\hline
\end{tabular}

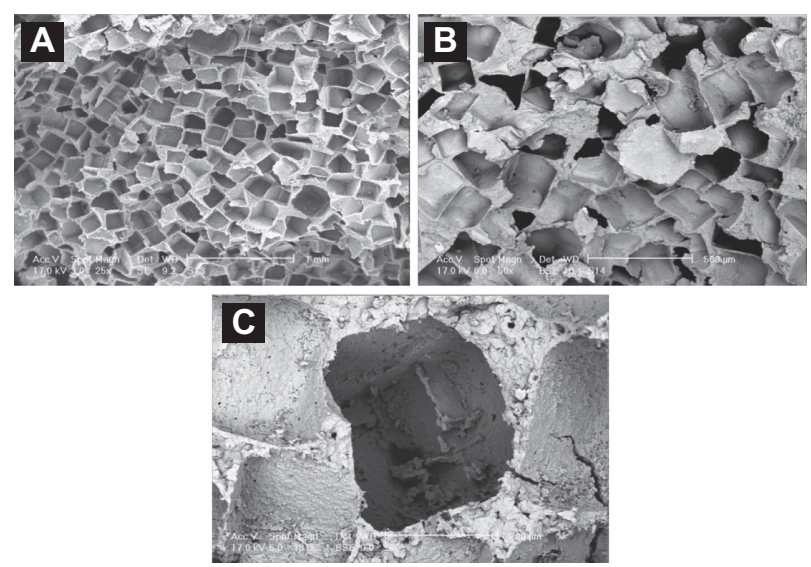

Figure 4 Low (A, B) and high (C) magnification SEM images of the composite scaffolds with $40 \mathrm{wt} \% \mathrm{n}-\mathrm{HA}$, prepared using $\mathrm{NaCl}$ leaching.

from our qualitative evaluation of the SEM images that the microstructure of n-HA/nylon 6,6 scaffold with both 40 and $60 \mathrm{wt} \% \mathrm{n}$-HA was extremely promising, because it was highly porous, with a well-developed network of interconnected pores, whose size can exceed $100 \mu \mathrm{m}$. In fact it has been underlined that high porosity is likely to boost osteogenesis in vivo, since bone regeneration involves vascularization, as well as recruitment and penetration of cells from the surrounding tissue. Moreover, $100 \mu \mathrm{m}$ is usually considered the minimum requirement for pore size to allow cell migration, vascularization, and transport processes; higher pore sizes could promote such phenomena further. ${ }^{42}$

\section{Mechanical properties}

Figure 6 shows the mechanical behaviors of the composite scaffolds with different n-HA content. We should note that both the compressive strength and the compressive modulus of the composite scaffolds are enhanced with an increase in n-HA content, which acts as the bioactive and reinforcing filler for the nylon 6,6 matrix. When the porosities of the samples varied from approximately $80 \%$ to $75 \%$, the compressive strength of the scaffolds gradually increased from 8.1 to $10.2 \mathrm{MPa}$, and the modulus from 375 to $446 \mathrm{MPa}$.
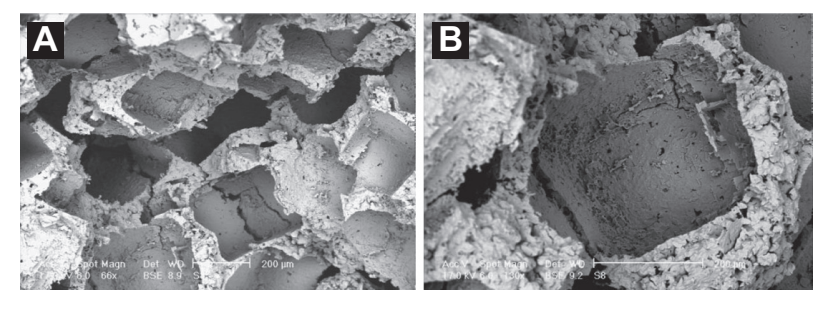

Figure 5 SEM images of the composite scaffolds with 60 wt\% n-HA: (A) the crosssection of the scaffold with a porosity of $75 \%$; (B) the micropores located on the pore walls of macropores in the scaffold. 

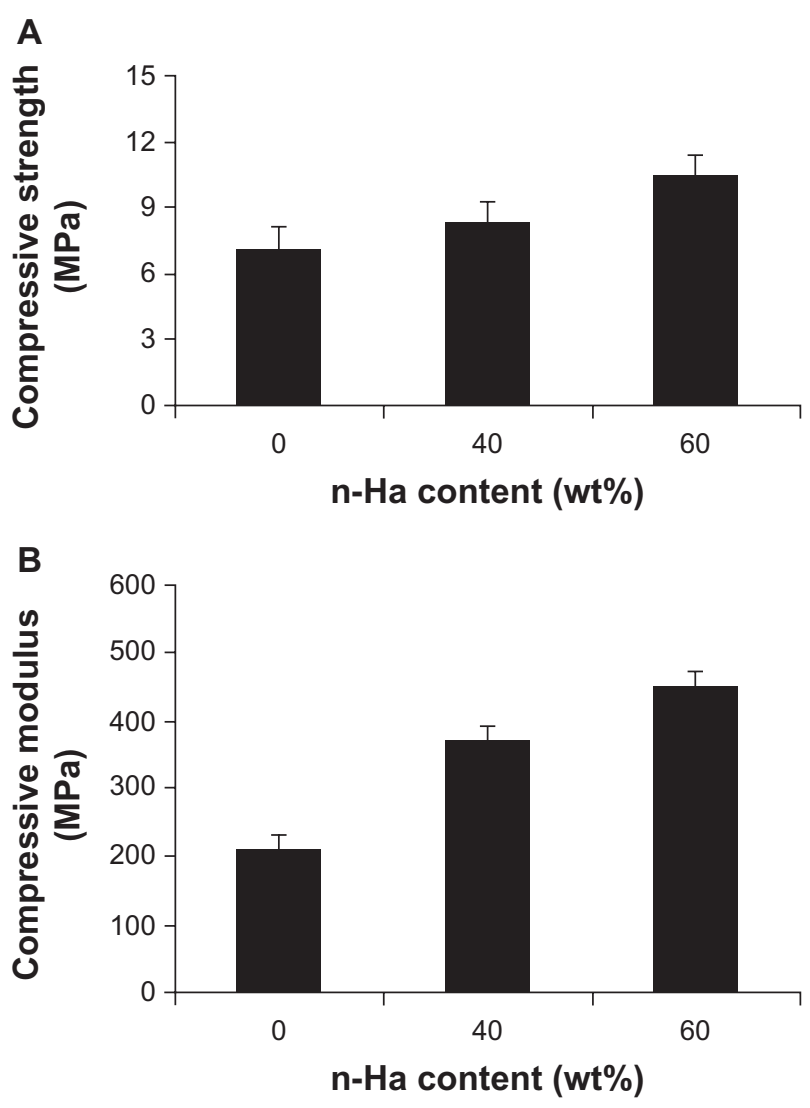

Figure 6 The influence of $\mathrm{n}$-HA content on the compressive strength (A) and modulus (B) of n-HA/nylon 6,6 scaffolds prepared by salt leaching/solvent casting technique.

These results are similar to the upper value of the strength of cancellous bone (12.2 MPa, with porosity of about $70 \%$ ), which has been regarded as the lowest porosity required for cell infiltration and proliferation and the ingrowth of new bone tissue. ${ }^{40,43,44}$ It is well known that it is difficult to achieve high compressive strength for porous materials because of the negative effects of the porous structure. So it is reasonable in this case that the compressive strength and modulus decreased with the growth of scaffold porosity.

\section{In vitro bioactivity evaluation}

Figures 7 and 8 present some selected images of the composite scaffold surfaces with different n-HA content
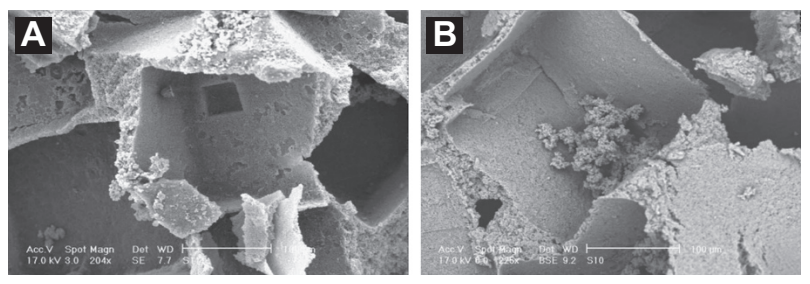

Figure 7 SEM micrographs of the 40 wt\% n-HA/nylon 6,6 composite scaffolds surface after soaking in the SBF for (A) 7 days and (B) 14 days.

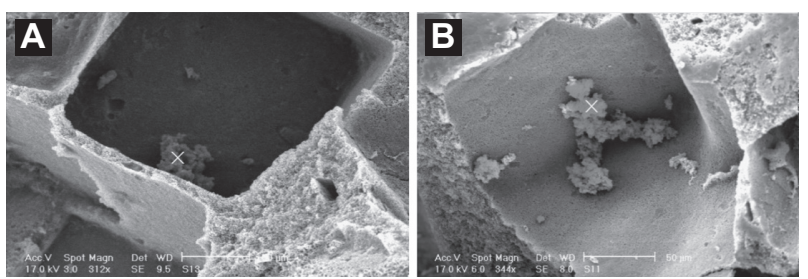

Figure 8 SEM micrographs of the 60 wt\% n-HA/nylon 6,6 composite scaffolds' surface after soaking in the SBF for (A) 7 days and (B) 14 days.

immersed in SBF for various lengths of time (7 and 14 days). As the immersion time is lengthened, the apatite's nucleation through the scaffold surface increases. The apatite's layer of spherical particle aggregates, with relatively small crystals, suggests a high nucleation rate. Our electron microscope observation confirmed that a calcium phosphate layer, of bone apatite, can efficiently grow on the surface and pore walls of the scaffold by incubation of the sample in a solution with an ionic composition similar to human blood plasma. ${ }^{45}$ The results of our study, and results from other authors ${ }^{45}$ indicate that the apatite formation mechanism could be as follows: the $\mathrm{HCl}$ in the SBF increases the number of polar groups on the nanocomposite surface which in turn increases their affinity with the silicate ions, which provide specific sites for the apatite nucleation. As a result, a very high number of apatite nuclei are formed on the nanomaterial surface during the incubation in SBF. EDX curves in Figure 9 indicate an increase in phosphorous and calcium contents after soaking in SBF for 7 and 14 days. The EDX analysis suggested that these spherical particles could be calcium-deficient and nonstoichiometric apatite with $\mathrm{Ca} / \mathrm{P}$ ratio of 1.53 and 1.60 for both $\mathrm{n}-\mathrm{HA} /$ nylon 6,6 composite scaffolds (40 and $60 \mathrm{wt} \%$ ) after immersion in SBF for 1 and 2 weeks, respectively. As the immersion time increased, the $\mathrm{Ca} / \mathrm{P}$ ratio increased until it reached a value of 1.67 , which corresponds to a biological apatite. This suggests that, under these conditions, the n-HA/ nylon 6,6 composite scaffolds behave as a bone substitute in tissue engineering. Other studies have reported that the induced apatite layer on the surfaces of different bioactive materials during their incubation in SBF was also calciumdeficient. ${ }^{46,47}$

\section{Conclusions}

We adapted an interfacial in situ synthesis method to the fabrication of bone-like n-HA/nylon 6,6 nanocomposites. This method provides the uniform distribution of n-HA needle-like particles in a nylon network, similar to normal bone and reduces their ability to agglomerate. Therefore, the high proportion of HA and uniform distribution of n-HA 
A

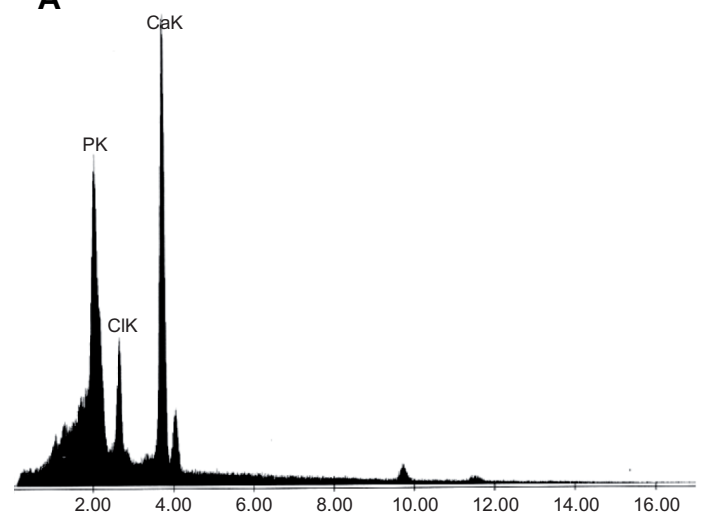

B

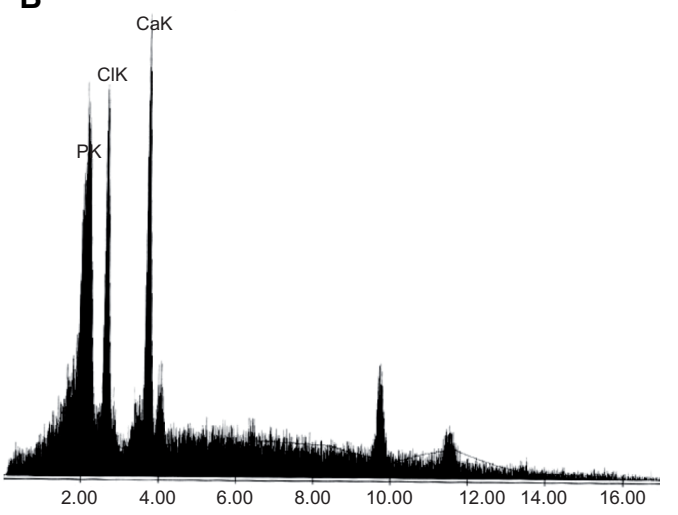

Figure 9 EDX analysis of the n-HA/nylon 6,6 composite scaffolds' surface after soaking in the SBF for (A) 7 days and (B) I4 days. The Ca/P ratio of the covering layer on the scaffold surface developed from 1.53 in I week to 1.60 in 2 weeks. The detection of $\mathrm{Cl}$ peak showed the salt not perfectly removed when the sample was rinsed with distilled water.

granules in the nylon network enable the scaffolding material to possess high bioactivity and sufficient mechanical strength. FT-IR and XRD analysis confirmed that chemical bonds were formed between n-HA and nylon 6,6 in composite powders. The aim of processing bone, tissue-engineered, scaffolds with a highly porous structure, desired pore size, and sufficient mechanical strength, encouraged us to focus on preparing scaffolds using the salt-leaching/solvent casting method and n-HA/nylon 6,6 nanocomposite powder. Our results demonstrated that these n-HA/nylon 6,6 composite scaffolds are three-dimensionally porous and that the compressive strength and modulus of $60 \mathrm{wt} \% \mathrm{n}-\mathrm{HA} /$ nylon 6,6 scaffold with an approximate porosity of $75 \%$ is comparable to the upper value strength of natural cancellous bone. The mean size of macropores in n-HA/nylon 6,6 scaffold with $40 \mathrm{wt} \%$ n-HA ranged from 200 to $500 \mu \mathrm{m}$, and on their walls there were micropores with pore sizes $<50 \mu \mathrm{m}$. The higher the percentage n-HA content, the thinner the pore walls, but this did not change the pore size of the scaffolds. Moreover, the presence of bioactive n-HA particles enhanced the scaffolds' bioactivity and improved their ability to induce the formation of an apatite layer on their surfaces. Therefore, the n-HA/ nylon 6,6 composite scaffolds with high n-HA content were similar to natural bone in bioactivity and mechanical properties, which makes them a possible candidate biomaterial suitable for use as bone substitutes.

\section{Acknowledgments}

The authors gratefully acknowledge the Islamic Azad University-Najafabad Branch for financial support for this work. The authors wish to thank A Chami and O Torabi for their help in laboratory testing and figure preparation, respectively.

\section{Disclosure}

The authors report no conflicts of interest in this work.

\section{References}

1. Misra SK, Baccaccini AR. Chapter 2. In: Baccaccini AR, Gough JE, editors. Tissue Engineering Using Ceramics and Polymers. Boca Raton, FL: Woodhead Publishing Limited and CRC Press LLC; 2007:72.

2. Hollister SJ, Taboas J, Schek RM, Lin CY, Chu TM. Chapter 6. In: Hollinger JO, Einhorn TA, Doll BA, Sfeir C, editors. Bone Tissue Engineering. Boca Raton, FL: CRC Press; 2005:167.

3. Boccaccini AR, Maquet V. Bioresorbable and bioactive polymer/ Bioglass composites with tailored pore structure for tissue engineering applications. Compos Sci Technol. 2003;63:2417-2429.

4. Maquet V, Boccaccini AR, Pravata L, Notingher I, Jérôme R. Porous poly(alpha-hydroxyacid)/Bioglass composite scaffolds for bone tissue engineering. I: Preparation and in vitro characterization. Biomaterials. 2004;25:4185-4194.

5. Verrier S, Blaker JJ, Maquet V, Hench LL, Boccaccini AR. PDLLA/ Bioglass composites for soft-tissue and hard-tissue engineering: an in vitro cell biology assessment. Biomaterials. 2004;25:3013-3021.

6. Blaker JJ, Maquet V, Jérôme R, Boccaccini AR, Nazhat SN. Mechanical properties of highly porous PDLLA/Bioglass composite foams as scaffolds for bone tissue engineering. Acta Biomater. 2005;1:643-652.

7. Maquet V, Boccaccini AR, Pravata L, Notingher I, Jérôme R, Preparation, characterization, and in vitro degradation of bioresorbable and bioactive composites based on Bioglass-filled polylactide foams. J Biomed Mater Res. 2003;A66:335-346.

8. Laurencin CT, Lu HH, Khan Y. Processing of polymer scaffolds: polymerceramic composite foams. In: Atala A, Lanza RP, editors. Methods of Tissue Engineering. San Diego, CA: Academic Press; 2002.

9. Eosoly S, Brabazon D, Lohfeld S, Looney L, Selective laser sintering of hydroxyapatite/poly-[epsilon]-caprolactone scaffolds. Acta Biomater. In press.

10. Garcia-Gonzalez CA, Vega-Gonzalez A, Lopez-Periago AM, Subra-Paternault P, Domingo C. Composite fibrous biomaterials for tissue engineering obtained using a supercritical $\mathrm{CO}_{2}$ antisolvent process. Acta Biomater. 2009;5:1094-1103.

11. Fabbri P, Bondioli F, Messori M, Bartoli C, Dinucci D, Chiellini F. Porous scaffolds of polycaprolactone reinforced with in situ generated hydroxyapatite for bone tissue engineering. J Mater Sci Mater Med. 2010;21:343-351.

12. Shor L, Guceri S, Wen X, Gandhi M, Sun W. Fabrication of threedimensional polycaprolactone/hydroxyapatite tissue scaffolds and osteoblast-scaffold interactions in vitro. Biomaterials. 2007;28:5291-5297. 
13. Taboas JM, Maddox RD, Krebsbach PH, Hollister SJ. Indirect solid free form fabrication of local and global porous, biomimetic and composite 3D polymer-ceramic scaffolds. Biomaterials. 2003;24:181-194.

14. Mondrinos MJ, Dembzynski R, Lu L, et al. Porogen-based solid freeform fabrication of polycaprolactone-calcium phosphate scaffolds for tissue engineering. Biomaterials. 2006;27:4399-4408.

15. Venugopal JR, Low S, Choon AT, Bharath Kumar A, Ramakrishna S. Nanobioengineered electrospun composite nanofibers and osteoblasts for bone regeneration. Artif Organs. 2008;32:388-397.

16. Wutticharoenmongkol P, Sanchavanakit N, Pavasant P, Supaphol P. Preparation and characterization of novel bone scaffolds based on electrospun polycaprolactone fibers filled with nanoparticles. Macromol Biosci. 2006;6:70-77.

17. Zhao J, Guo LY, Yang XB, Weng J. Preparation of bioactive porous HA/PCL composite scaffolds. Appl Surf Sci. 2008;255:2942-2946.

18. Bretcanu O, Misra SK, Mohammad Yunos D, et al. Electrospun nanofibrous biodegradable polyester coatings on Bioglass-based glass-ceramics for tissue engineering. Mater Chem Phys. 2009;118. 420-426.

19. Boccaccini AR, Notingher I, Maquet V, Jérôme R. Bioresorbable and bioactive composite materials based on polylactide foams filled with and coated by Bioglass particles for tissue engineering applications. $J$ Mater Sci Mater Med. 2003;14:443-450.

20. Baino F, Verné E, Vitale-Brovarone C. Feasibility, tailoring and properties of polyurethane/bioactive glass composite scaffolds for tissue engineering. J Mater Sci Mater Med. 2009;20:2189-2195.

21. Roether JA, Boccaccini AR, Hench LL, Maquet V, Gautier S, Jérôme R. Development and in vitro characterisation of novel bioresorbable and bioactive composite materials based on polylactide foams and Bioglass for tissue engineering applications. Biomaterials. 2002; 23:3871-3878.

22. Gamble JE. Chemical Anatomy, Physiology and Pathology of Extracellular Fluid. Cambridge, MA: Harvard University Press; 1967.

23. Blaker JJ, Bismarck A, Boccaccini AR, Young AM, Nazhat SN. Premature degradation of poly([alpha]-hydroxyesters) during thermal processing of Bioglass-containing composites. Acta Biomater. 2010; 6:756-762.

24. Rezwan K, Chen QZ, Blaker JJ, Boccaccini AR. Review biodegradable and bioactive porous polymer/inorganic composite scaffolds for bone tissue engineering. Biomaterials. 2006;27:3413-3431.

25. Cheung HY, Lau KT, Lu TP, Hui D. A critical review on polymer-based bioengineered materials for scaffold development. Composites: Part B. 2007;38:291-300.

26. Shirtliff VJ, Hench LL. Bioactive materials for tissue engineering, regeneration and repair. J Mater Sci. 2003;38:4697-4707.

27. Sabir MI, Xu X, Li Li. A review on biodegradable polymeric materials for bone tissue engineering applications. J Mater Sci. 2009;44: 5713-5724.

28. Chen Q, Roether JA, Boccaccini AR. Chapter 6. In: Ashammakhi N, Reis R, Chiellini F, editors. Chapter 6 Tissue Engineering Scaffolds from Bioactive Glass and Composite Materials. Topics in tissue engineering. Vol 4. 2008:1-27.
29. Strocchi R, Orsini G, Iezzi G, et al. Bone regeneration with calcium sulfate: evidence for increased angiogenesis in rabbits. J Oral Implantol. 2002;28:273-278.

30. Couri CJ, Maze GI, Hinkson DW, Byran H, Deborah V. Medical grade calcium sulfate hemihydrate versus expanded polytetrafluoroethylene in the treatment of mandibular class II furcations. $J$ Periodontol. 2002;73:1352-1359.

31. Springer ING, Fleiner B, Jepsen S, Acil Y. Culture of cells gained from temporomandibular joint cartilage on non-absorbable scaffolds. Biomaterials. 2001;22:2569-2577.

32. Xu Q, Lu H, Zhang J, Lu G, Deng Z, Mo A. Tissue engineering scaffold material of porous nanohydroxyapatite/polyamide 66. Int J Nanomed. 2010;5:331-335.

33. Deng C, Weng J, Cheng QY, et al. Choice of dispersants for the nanoapatite filler of polylactide-matrix composite biomaterial. Current Applied Physics. 2007;7:679-682.

34. Guobao W, Ma PX. Structure and properties of nano-hydroxyapatite/ polymer composite scaffolds for bone tissue engineering. Biomaterials 2004;25:4749-4757.

35. Kokubo T, Takadama $\mathrm{H}$. How useful is SBF in predicting in vivo bone bioactivity. Biomaterials. 2006;27:2907-2915.

36. Li Yubao, Wijn J, Klein CPAT, Meer S, Groot K. Preparation and characterization of nanograde osteoapatite-like rod crystals. J Mater Sci Mater Med. 1994;5:252-255.

37. Liu XH, Wu QJ, Lars A. Polymorphism in polyamide 66/clay nanocomposites. Polymer. 2002;43:4967-4972.

38. Zuo Y, Li YB, Li JD, Zhang X, Liao HB, Wang YY. Novel bio-composite of hydroxyapatite reinforced polyamide and polyethylene: composition and properties. Mater Sci Eng A. 2007;452-453;72:512-517.

39. Salgada AJ, Coutinho OP, Reis RL. Bone tissue engineering: state of the art and future trends. Macromol Biosci. 2004;4:743-765.

40. Hutmacher DW. Scaffolds in tissue engineering bone and cartilage. Biomaterials. 2000;21:2529-2543.

41. Cerroni L, Filocamo R, Fabbri M, Piconi C, Caropreso S, Condo SG. Growth of osteoblast-like cells on porous hydroxyapatite ceramics: an in vitro study. Biomol Eng. 2002;19:119-124.

42. Karageorgiou V, Kaplan D. Review porosity of 3D biomaterial scaffolds and osteogenesis. Biomaterials. 2005;26:5474-5491.

43. Salgada AJ, Coutinho OP, Reis RL. Bone tissue engineering: state of the art and future trends. Macromol Biosci. 2004;4:743-765.

44. Ma PX. Scaffolds for tissue fabrication. Mater Today. 2004;7:30-40.

45. Neo M, Kotani S, Fujita Y, Yamamuro T. Differences in ceramic-bone interface between surface-active ceramics and resorbable ceramics: a study by scanning and transmission electron microscopy. J Biomed Mater Res. 1992;26:255-267.

46. Radin S, Ducheyne P, Falaize S, Hammond A. In vitro transformation of bioactive glass granules into Ca-P shells. J Biomed Mater Res. 2000; 49:264-272.

47. Kim HM, Kishimoto K, Miyaji F, et al. Composition and structure of the apatite formed on PET substrates in SBF modified with various ionic activity products. J Biomed Mater Res. 1999;46:228-235.
International Journal of Nanomedicine

\section{Publish your work in this journal}

The International Journal of Nanomedicine is an international, peerreviewed journal focusing on the application of nanotechnology in diagnostics, therapeutics, and drug delivery systems throughout the biomedical field. This journal is indexed on PubMed Central,

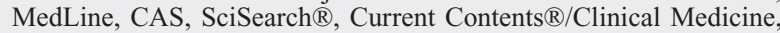

\section{Dovepress}

Journal Citation Reports/Science Edition, EMBase, Scopus and the Elsevier Bibliographic databases. The manuscript management system is completely online and includes a very quick and fair peer-review system, which is all easy to use. Visit http://www.dovepress.com/ testimonials.php to read real quotes from published authors 